Brit. J. industr. Med., 1952, 9, 146.

\title{
CARDIOVASCULAR DISEASE IN COTTON WORKERS PART II : A CLINICAL STUDY WITH SPECIAL REFERENCE TO HYPERTENSION
}

BY

\author{
R. S. F. SCHILlING, N. GOODMAN, and J. G. O'SULLIVAN \\ From the Nuffield Department of Occupational Health, Manchester University
}

(RECEIVED FOR PUBLICATION FEBRUARY 15, 1952)

The object of this investigation was to find out if cotton workers exposed to fine dust had a higher incidence of cardiovascular and renal disease, and in particular of hypertension, than cotton workers not so exposed.

High death rates from cardiovascular, renal, and respiratory diseases among cotton workers have been recorded by the Registrar General since 1891 . In a previous paper Schilling and Goodman (1951) showed that strippers and grinders, who are more heavily exposed to fine cotton dust than any other group, had the highest death rate of cotton workers for both cardiovascular-renal and respiratory diseases.

Some of the cardiovascular mortality could be explained by methods of " book-keeping". Before 1939 the Registrar General's rules for selecting one cause of death from certificates with multiple causes meant that many respiratory deaths were allocated to the cardiovascular group, but when a correction was attempted there still appeared to be a real excess mortality from cardiovascular-renal disease among the strippers and grinders.

Clinical studies of cotton workers by Collis (1909), Prausnitz (1936), and O'Sullivan and Dingwall-Fordyce (1950), and statistical investigations of their morbidity by Bradford Hill (1930) and Harvey (1939) have confirmed a high incidence of respiratory disease among strippers and grinders, but until now the only suggestion of a cardiovascular hazard is in the Registrar General's statistics.

Since 1910 methods of dust control in cotton card-rooms have steadily improved and exposure to cotton dust has been substantially reduced. Conditions today are so changed for the better that the respiratory hazard may have been considerably reduced, and the cardiovascular-renal hazard, if ever there was one, may have disappeared.'

Nevertheless, because of the interest and importance of any relationship between working conditions and cardiovascular and renal disease, it was decided to investigate clinically a group of cotton workers. An attempt was also made at the same time to determine the extent of respiratory disease under present day environmental conditions. Special attention was given to the incidence of " essential " hypertension, because it has been suggested that cotton dust exposure may be a cause of its occurrence among cotton workers (Brit. med. J., 1947).

\section{Method of Investigation}

The trades included in the group exposed to dust were strippers and grinders, blow-room workers, carders, and under-carders. The group not exposed to fine cotton dust comprised weavers and warehousemen living in the same towns, and where possible, working in the same mills.

The mills chosen were those spinning raw cotton of the lower grades, and were in no way a representative sample of the cotton spinning industry. At this stage of the enquiry it was more important to choose populations likely to show positive results, so mills spinning finer grades of raw cotton and waste cotton, where there is thought to be less dust, were not included.

There were two series of examinations: series A, the first to be done, in which a group of men between the ages of 35 and 65 was examined, and series $B$, in which a further sample between the ages of 50 and 60 was examined.

\section{Series A}

The experimental and control groups were selected as follows.

Experimental Group (Card- and Blow-room Workers).- This group comprised all men between 35 and 65 who had worked in the card- and blowrooms for at least 10 years. One hundred and forty-five men were originally selected from the firms' books, but on more detailed examination 
42 had to be rejected for a number of reasons : because they were in fact outside the age range, or had less than 10 years' exposure to cotton dust, or had substantial exposure to other dusts. One hundred and three men therefore were included in the final analysis. No man in this group refused to be examined.

Control Group (Weavers and Warehousemen). -This group originally comprised 113 men between 35 and 65 , who had worked in weaving sheds or warehouses for at least 10 years. They were selected from the firms' books to form a sample matched with the experimental group for age and length of time in the cotton industry. It was originally intended to have equal experimental and control groups, but this was not possible. Twenty men selected from the firms' books were found on detailed examination not to fulfil the necessary criteria, and had to be rejected. Ninety-three men were therefore included in the final analysis; six weavers who refused to be examined were replaced by others from the same mills. There was no reason to believe that this refusal was related to the problem under investigation. (Five men were in one department, and it appeared to be a group decision to refuse. The other man was a Christian Scientist.)

Clinical and Social Records.-All the men were interviewed and examined at their place of work. Occupational and family histories were recorded in detail. Clinical histories were taken with special reference to respiratory, renal, and cardiovascular diseases. The clinical examination was divided into two stages. The first stage comprised urine analysis, the recording of certain body measurements, clinical examination of heart and chest, and the recording of a "casual " blood pressure at the beginning of the examination. The second stage was devoted entirely to blood pressure recordings, which were made by another observer. Recordings were taken with the patient lying down, as far as possible in silence, after the procedure of the examination had been explained. Systolic and diastolic pressures were taken every three minutes and continued for 10 readings, or until the pressure stabilized at $130 / 70$, or below. Readings were taken to the nearest multiple of 5 . The technique adopted in taking pressures was that recommended by the Committee appointed by the Cardiac Society of Great Britain and Ireland (1939). All pressures were recorded on the left arm. Calibration at regular intervals showed no appreciable difference between the two manometers used, which were of the Accosson type.
Control and experimental groups were initially mixed and examined in random order to reduce the possibility of an external factor, such as emotional stress due to disturbance in the examination room, or the effect of meals, influencing one group more than the other. Where both weavers and card-and blow-room workers were working in the same mill, the observer recording pressures in the second stage of the examination did not know to which group the worker belonged, but it was not possible to make this a universal condition in the examinations.

\section{The Findings in Series A}

The two groups were comparable in respect of age and length of employment in the cotton industry (see Appendix B).

Cardiovascular and Renal Disease.-The incidence of cardiovascular and renal disease, as detected by a single clinical examination in a cotton mill, was not high. In the experimental group there was one man with rheumatic heart disease and two with renal disease. In the control group there was one man with rheumatic heart disease and one with renal disease (for details see Appendix A).

Blood Pressures.-The mean systolic and diastolic pressures of the experimental and control groups are compared in Table 1. There is a statistically significant difference at the $5 \%$ level between the "casual" diastolic pressures of the experimental and control groups. The "casual" reading, however, is probably the least reliable for this type of

TABLE 1

MEAN OF SYSTOLIC AND DIASTOLIC PRESSURES OF THE EXPERIMENTAL AND CONTROL GROUPS IN SERIES A

\begin{tabular}{|c|c|c|c|c|}
\hline \multirow[t]{2}{*}{. } & \multicolumn{2}{|c|}{$\begin{array}{l}\text { Experimental } \\
\text { Group }\end{array}$} & \multicolumn{2}{|c|}{$\begin{array}{c}\text { Control } \\
\text { Group }\end{array}$} \\
\hline & Casual $\dagger$ & Lowest & Casual $\ddagger$ & Lowest \\
\hline Number of men & 100 & 103 & 92 & 93 \\
\hline $\begin{array}{l}\text { Mean of systolic } \\
\text { pressures (mm.) }\end{array}$ & $141 \cdot 1$ & $127 \cdot 7$ & $141 \cdot 5$ & $127 \cdot 7$ \\
\hline S.E. of mean $\quad$. & 1.9 & $1 \cdot 6$ & 1.9 & $1 \cdot 7$ \\
\hline $\begin{array}{c}\text { Mean of diastolic } \\
\text { pressures (mm.) }\end{array}$ & $87 \cdot 6 \S$ & $82 \cdot 0$ & $84 \cdot 7 \S$ & $80 \cdot 3$ \\
\hline S.E. of mean $\quad \ldots$ & $1 \cdot 0$ & $0 \cdot 9$ & $1 \cdot 0$ & 0.9 \\
\hline
\end{tabular}

+3 casual pressures not taken.

\$ 1 casual pressure not taken.

$\S \mathrm{t}=2.08, \quad \mathrm{P}=0.04$. 
TABLE 2

MEAN SYSTOLIC AND DIASTOLIC PRESSURES OF THE EXPERIMENTAL AND CONTROL GROUPS BY AGES IN SERIES A (LOWEST PRESSURES)

\begin{tabular}{|c|c|c|c|c|c|c|c|c|c|c|}
\hline \multirow[t]{2}{*}{ Age } & \multirow[t]{2}{*}{$\cdots$} & \multirow[t]{2}{*}{$\cdots$} & \multicolumn{2}{|l|}{$35-$} & \multicolumn{2}{|l|}{$40-$} & \multicolumn{2}{|l|}{$50-$} & \multicolumn{2}{|c|}{$60-64$} \\
\hline & & & Experimental & Control & Experimental & Control & Experimental & Control & Experimental & Control \\
\hline Number & .. & . & 12 & 17 & 50 & 39 & 31 & 28 & 10 & 9 \\
\hline \multicolumn{3}{|c|}{$\begin{array}{c}\text { Mean systolic read- } \\
\text { ings } \quad \ldots\end{array}$} & $119 \cdot 3$ & $123 \cdot 2$ & $124 \cdot 0$ & $125 \cdot 5$ & $135 \cdot 5$ & $130 \cdot 2$ & $132 \cdot 5$ & $138 \cdot 3$ \\
\hline \multicolumn{3}{|c|}{ S.E. of mean } & $2 \cdot 9$ & $3 \cdot 6$ & $1 \cdot 8$ & $2 \cdot 5$ & $3 \cdot 6$ & $3 \cdot 6$ & 5.9 & $5 \cdot 5$ \\
\hline \multicolumn{3}{|c|}{$\begin{array}{l}\text { Mean diastolic read- } \\
\text { ings } \quad .\end{array}$} & $80 \cdot 0$ & $80 \cdot 3$ & $80 \cdot 8$ & $78 \cdot 5$ & $84 \cdot 4$ & $81 \cdot 6$ & $83 \cdot 5$ & $83 \cdot 9$ \\
\hline \multicolumn{3}{|c|}{ S.E. of mean } & $1 \cdot 5$ & $2 \cdot 3$ & $1 \cdot 1$ & $1 \cdot 1$ & $1 \cdot 8$ & $1 \cdot 6$ & $3 \cdot 7$ & $3 \cdot 1$ \\
\hline
\end{tabular}

study of blood pressures, as it may be affected by many factors, such as apprehension about the examination, and recent exercise. Diastolic pressures in some people are difficult to judge unless repeated recordings are made. Hence this finding may have little or no clinical significance. All comparisons from now on will be based on the lowest pressures recorded in the second stage of the examination.

In Table 2 the mean systolic and diastolic pressures of the two groups are compared by ages. It is only in the 50-60 age group that both the mean systolic and diastolic pressures are higher for the card- and blow-room workers than for the weavers and warehousemen, but the difference is small and not statistically significant. Card- and blow-room workers between 60 and 64 show surprisingly low systolic pressures. There is not the expected rise with age. This finding cannot be explained satisfactorily, but the numbers in this age group are small, and it may be that the men we examined were adversely selected from the point of view of investigating hypertension. The combined effects of hypertension and of the respiratory disease, which is common among card- and blowroom workers, may have forced men with relatively mild degrees of hypertension to retire from the dusty jobs.
The age distribution of strippers and grinders and weavers at the 1931 census (more recent figures are not available) supports this suggestion. It shows that the former group have proportionately fewer men over 55 than the latter (18.5\% compared with $24 \%$ ).

Hypertension.-Herndon (1946) and Levy, Hillman, Stroud, and White (1944), in their studies of large groups of apparently healthy men, regarded pressures which are consistently more than 150 systolic or $\mathbf{9 0}$ diastolic as indicative of hypertension. We adopted a more severe standard and did not regard a man as suffering from hypertension unless both his lowest systolic and diastolic pressures were at or above both the levels of 150 and 90 respectively. The incidence of hypertension is shown in Table 3 by ages. The only obvious difference between the two groups (as one would expect from previous results) occurs in the 50-59 age group, but the difference is not statistically significant. (Clinical details of men with hypertension are given in Appendix A.)

Thus a further group, Series B, comprising all men in other mills between the ages of 50 and 60 employed for more than 10 years, was examined in an attempt to get a more definite result.

TABLE 3

INCIDENCE OF HYPERTENSION IN AGE GROUPS IN THE EXPERIMENTAL AND CONTROL GROUPS IN SERIES A

\begin{tabular}{|c|c|c|c|c|c|c|c|c|c|c|}
\hline \multirow[t]{2}{*}{ Age } & & \multicolumn{2}{|l|}{$35-$} & \multicolumn{2}{|l|}{$40-$} & \multicolumn{2}{|l|}{$50-$} & \multicolumn{2}{|c|}{$60-64$} \\
\hline & & & Experimental & Control & Experimental & Control & Experimental & Control & Experimental & Control \\
\hline Number & $\ldots$ & .. & 12 & 17 & 50 & 39 & 31 & 28 & 10 & 9 \\
\hline \multicolumn{3}{|c|}{$\begin{array}{c}\text { Lowest pressures at } \\
\text { or above } 150 / 90 . .\end{array}$} & 0 & 1 & 0 & 1 & 9* & $3 *$ & 2 & 3 \\
\hline
\end{tabular}

$* \cdot 20>P>\cdot 10$. 


\section{Series B}

Twenty-eight men were examined in the experimental group and 22 in the control group. A further 10 men in the experimental group and 11 in the control group were examined, but had to be discarded for the same reasons as given in Series A. No card- or blow-room workers refused examination, but six weavers refused. Five of them, who all came from the same mill, had decided as a group not to cooperate, and they were replaced by five men from another mill in the same area. The other man refused because he said he was in good health.

\section{The Findings in Series B}

For length of time in the industry and for age, the experimental and control groups were comparable (See Appendix B).

Cardiovascular and Renal Disease.-In the experimental and control groups there were respectively one man and two men with rheumatic heart disease. No man in either group was found to have renal disease. (See Appendix A.)

Blood Pressures and Hypertension.-In Table 4 the mean systolic and diastolic pressures of, and the incidence of hypertension in, the experimental and control groups are compared.

None of the differences between the pressures of the experimental and control groups is statistically significant. The experimental group shows a higher incidence of hypertension than the control group.*

\section{Findings for Series A and B}

We will consider the two series together, as they appear to be reasonably similar for blood pressures (see Tables 2 and 4). The data for the combined series are given in Table 5 and Fig. 1.

There are significant differences between the experimental and control groups for (1) the proportion of men with hypertension, and (2) the mean systolic pressure levels.

There are similar, though not significant, differences for the mean diastolic pressures of the combined series. Similar trends are found among the men

\footnotetext{
* In another mill, not planned to be included in either series, similar differences between the experimental and control groups were also found. Men employed in this mill were examined after the field studies on Series B had been completed. These results could not be included because one stripper and grinder out of eight, and eight weavers out of 21 , refused examination, and both experimental and control groups showed higher mean systolic and diastolic pressures than the men of this age group in other mills. At all other mills the men were seen first by one of the observers or the medical officer or welfare officer employed by the mill. At this mill the men had to be seen first by the local Trade Union secretary. It was he alone who explained the purpose of the investigation and persuaded the men to the men to cooperate. explain both the high lapse rate and the higher pressure levels, which the part of the men. The results of these examinations are given in the part of the
}

TABLE 4

MEAN OF SYSTOLIC AND DIASTOLIC PRESSURES AND INCIDENCE OF HYPERTENSION IN EXPERIMENTAL AND CONTROL GROUPS IN SERIES B

\begin{tabular}{|c|c|c|}
\hline & $\begin{array}{l}\text { Experi- } \\
\text { mental } \\
\text { Group }\end{array}$ & $\begin{array}{l}\text { Control } \\
\text { Group }\end{array}$ \\
\hline Number of men (aged 50-59) & 28 & 22 \\
\hline Mean of systolic pressures .. & $140 \cdot 0^{*}$ & $129 \cdot 5^{*}$ \\
\hline S.E. of mean _. $\quad \ldots$ & $4 \cdot 3$ & $2 \cdot 5$ \\
\hline Mean of diastolic pressures .. & $85 \cdot 5$ & $81 \cdot 6$ \\
\hline S.E. of mean $\quad \ldots \quad \quad \ldots$ & $2 \cdot 4$ & $2 \cdot 0$ \\
\hline $\begin{array}{l}\text { Lowest pressures at or above } \\
150 / 90\end{array}$ & 6 & 1 \\
\hline
\end{tabular}

in the rejected mill. None of these results conflict in any way, but as the levels of significance are low it is all the more necessary to scrutinize these findings to see if factors not directly related to occupation may be responsible for the differences found.

Observer Error.-The higher incidence of hypertension found among the card- and blow-room workers could quite simply be due to conscious or unconscious bias on the part of the investigators. There are two possible sources of observer error. First the difference could arise through one or all observers being biased to read high for the experimental and/or low for the control group. It was originally planned to eliminate this source of error

TABLE 5

MEAN OF SYSTOLIC AND DIASTOLIC PRESSURES AND INCIDENCE OF HYPERTENSION IN EXPERIMENTAL AND CONTROL GROUPS IN BOTH SERIES

\begin{tabular}{|c|c|c|}
\hline & $\begin{array}{l}\text { Experi- } \\
\text { mental } \\
\text { Group }\end{array}$ & $\begin{array}{l}\text { Control } \\
\text { Group }\end{array}$ \\
\hline Number of men (aged 50-59) & 59 & 50 \\
\hline Mean of systolic pressures ... & $137 \cdot 9 *$ & $129.9 *$ \\
\hline S.E. of mean $\quad \ldots \quad \ldots$ & $2 \cdot 8$ & $2 \cdot 2$ \\
\hline Mean of diastolic pressures ... & $84.9 \dagger$ & $81 \cdot 6 \dagger$ \\
\hline S.E. of mean $\quad \ldots \quad \ldots$ & $1 \cdot 4$ & $1 \cdot 3$ \\
\hline $\begin{array}{l}\text { Lowest pressures at or above } \\
150 / 90\end{array}$ & $15^{*}$ & $4^{*}$ \\
\hline
\end{tabular}

- $\mathbf{P}<.05 . \quad$ † $\mathbf{P}>\cdot 05$. 
DISTRIBUTION OF LOWEST PRESSURES

STRIPPERS AND GRINDERS

WEAVERS $\square$

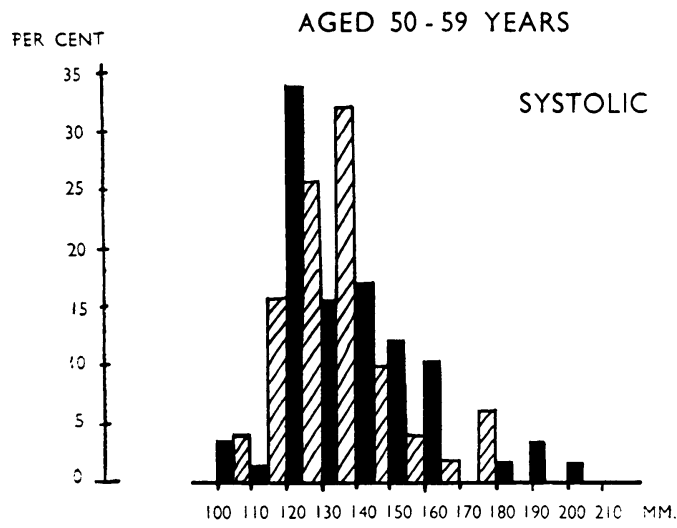

PER CENT
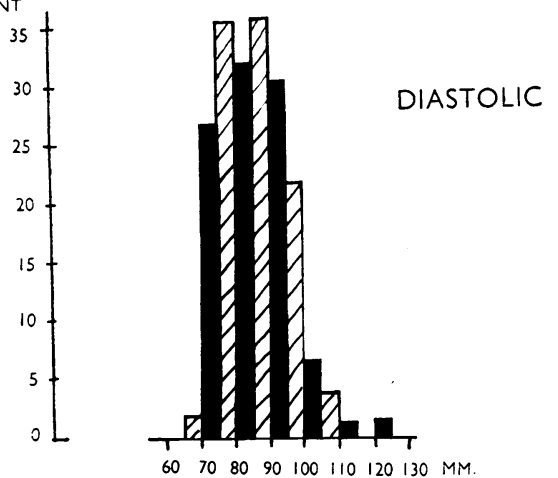

FIG. 1

by ensuring that observers who took the repeated pressures in the second stage of the examination which gave the lowest pressures would not know whether the man belonged to the experimental or control group.

This was only possible at the beginning of the investigation, when we could find mills employing both card- and blow-room workers and weavers at the same place. We can, however, test for this error by comparing the pressures of men whose jobs were known to the observer, with the pressures of men whose jobs were not known. Such a comparison is made in Table 6 for the 50-59 age group. It will be seen that there is no evidence that the knowledge of a man's job biased the observers. Secondly, another type of observer error would arise if one observer read low by comparison with other observers and took a greater proportion of the lowest pressures of the control group ; or if he read high and took a greater proportion of the experimental group's pressures.
TABLE 6

THE INCIDENCE OF HYPERTENSION AND MEAN OF PRESSURE LEVELS OF MEN IN 50-59 AGE GROUP WITH JOBS UNKNOWN AND KNOWN TO THE OBSERVER IN THE COMBINED SERIES

\begin{tabular}{l|c|c|c|c}
\hline & \multicolumn{2}{|c|}{$\begin{array}{c}\text { Experimental } \\
\text { Group }\end{array}$} & \multicolumn{2}{|c}{$\begin{array}{c}\text { Control } \\
\text { Group }\end{array}$} \\
\cline { 2 - 5 } & $\begin{array}{c}\text { Job } \\
\text { Known }\end{array}$ & $\begin{array}{c}\text { Job } \\
\text { Un- } \\
\text { known }\end{array}$ & $\begin{array}{c}\text { Job } \\
\text { Known }\end{array}$ & $\begin{array}{c}\text { Job } \\
\text { Un- } \\
\text { known }\end{array}$ \\
\hline $\begin{array}{c}\text { Number of men } \\
\text { Number with S/D } \geqslant\end{array}$ & 46 & 11 & 22 & 28 \\
$150 / 90$ & 4 & 1 & 3 \\
$\begin{array}{c}\text { Mean of systolic } \\
\text { pressures }\end{array}$ & 137.9 & 137.7 & 129.5 & 130.2 \\
$\begin{array}{c}\text { Mean of diastolic } \\
\text { pressures }\end{array}$ & 85.6 & 83.8 & 81.6 & 81.6 \\
\hline
\end{tabular}

Six independent readings by observers on the same subjects were always within a range of $5 \mathrm{~mm}$. of mercury.

For the 50-59 age group observer A took 47 of the 59 pressures of the experimental group and 40 out of 50 of the control group. As the proportion of pressures taken by the observer who took more pressures than all the other observers together was the same for both groups, it would not matter unduly if he read consistently high or low, unless he read high only for the experimental group or low only for the control group. We have already tested for the latter error in all observers and find no evidence of it, but it is possible to test specifically for this error in Observer A. The observed and expected numbers read by $A$, at the $150 / 90$ level or above, for the experimental and control groups were as follows :-

\section{0-59 AGE GROUP}

\begin{tabular}{l|c|c|c|c|c}
\hline & $\begin{array}{c}\text { Total } \\
\text { Number }\end{array}$ & $\begin{array}{c}\text { Read A } \\
\text { by }\end{array}$ & $\begin{array}{c}\text { Total } \\
\text { at or } \\
\text { above } \\
150 / 90 \\
\text { Level }\end{array}$ & $\begin{array}{c}\text { At or above } \\
150 / 90 \\
\text { Read by A }\end{array}$ \\
\begin{tabular}{c|c|c|} 
Ex- \\
pected
\end{tabular} & $\begin{array}{c}\text { Ob- } \\
\text { served }\end{array}$ \\
\hline $\begin{array}{c}\text { Experimental } \\
\text { group } \\
\begin{array}{c}\text { Control } \\
\text { group }\end{array}\end{array}$ & 59 & 47 & 15 & $11 \cdot 9$ & 12 \\
\hline
\end{tabular}

There is no evidence that $\mathrm{A}$ was reading high for the experimental group or low for the control group.

Thus observer errors are not likely causes for the differences found between the pressures of the experimental and control groups. The suggestion 
therefore is that the difference is a real one, and we must now examine other possible reasons for it.

Obesity and Body Measurements.-Several observations have been made on the correlation between obesity and blood-pressure, notably those by Symonds (1923) and Treadgold (1933).

In Series $\mathbf{A}$ the weavers as a whole were slightly heavier and shorter than the card- and blow-room workers. In series B the latter group was heavier, but the mean heights of the weavers and the cardand blow-room workers were identical. Thus it is unlikely that obesity was responsible for this difference.

Robinson and Brucer (1940) showed that bodybuild, as indicated by the ratio of chest circumference to height, was closely correlated with hypertension, and that obesity occurred most frequently in the lateral or broad-built types. They concluded that body-build, regardless of weight, determines in a great measure the predisposition of any individual to hypertension and that the role of obesity in hypertension is small. Among the men in the 50-59 age group, the grades of body-build described by Robinson and Brucer were similarly distributed among the experimental and control groups.

There was no evidence that the higher incidence of hypertension among the card- and blow-room workers was due to anthropometric differences between the groups.

Heredity.-Studies of family histories of patients with hypertension by Platt (1947), Weitz (1923), Hines (1937), and Ayman (1934) have shown that heredity is a factor of importance in the aetiology of " essential" hypertension. Our groups must now be examined to see if this result can be explained by heredity.

The method described by Platt (1947) for classifying family histories into four groups, positive, probable, incomplete, and negative, was adopted. In this study $42 \%$ of all the men gave incomplete family histories, whereas in Platt's series of 187 cases this proportion was only $21 \%$. A possible explanation for this difference is that Platt's patients were ill enough to attend hospital and were probably aware of their complaint, whereas the men in our series were fit enough to work and no one of them was aware that he had hypertension. It has been stressed by Doll and Buch (1950) and others, that the patient who knows he has a particular disease is more likely to be interested in searching out similar cases in his family than the patient who is not suffering from, or does not know he has, a disease.

With such a high proportion of incomplete family histories we cannot say to what extent $\mathrm{E}^{*}$ heredity influenced our result, although there was no evidence that it had done so. Card- and blowroom workers did not appear to have a stronger familial tendency to hypertension than weavers. Each group had $22 \%$ of men with positive family histories of hypertension.

In this series the family history did not appear to influence the blood pressure significantly. Men with positive and probably positive family histories were grouped together and compared with the men with negative family histories. An analysis of variance showed that for the systolic pressures only the variation between occupational groups was significant, but it was not so between histories for either the systolic or diastolic pressures, nor was there any evidence of a significant interaction between histories and occupational groups.

Renal Disease.-There was no difference in the incidence of renal disease found in the two groups, but the clinical methods used had to be crude, and it is possible that the higher incidence of hypertension in the card- and blow-room workers might be caused by renal disease which we failed to diagnose.

If we compare the medical histories of the two groups (all ages) for diseases such as nephritis, trench fever, and scarlet fever, the experimental and control groups respectively had 18 and 23 men with suggestive histories of renal disease. It therefore seems unlikely that hypertension secondary to undetected renal disease was the cause of the difference between the two groups.

Industrial Respiratory Disease.-The incidence and severity of industrial respiratory disease (byssinosis) among the card- and blow-room workers examined must be considered, as it may bear some relation to the incidence of hypertension.

Sixty-three per cent. of the men were found to be complaining of tightness of their chests although only $11 \%$ showed any serious disability which was most likely to be due to emphysema.

Pneumoconiosis and emphysema are important aetiological factors in pulmonary hypertension (Rosenthal, 1930 ; McMichael, 1948 ; Gelfand, 1951), but their aetiological importance in systemic hypertension or the effect of a raised pulmonary pressure on the systemic pressure has not been clearly established. Gelfand found in cases of cor pulmonale that the systemic pressure was usually normal. Parkinson and Hoyle (1937), however, found that systemic hypertension was one of the diseases most commonly associated with emphysema in a series of patients attending hospitat; but these patients may have sought treatron their emphysema because of the added complication of 
INCIDENCE AND GRADE OF BYSSINOSIS AMONG THE CARDAND BLOW-ROOM WORKERS*

\begin{tabular}{|c|c|c|c|}
\hline Grade & & $\begin{array}{l}\text { Number } \\
\text { of Men }\end{array}$ & $\begin{array}{l}\text { Per- } \\
\text { centage }\end{array}$ \\
\hline $\mathrm{O}$ & No symptoms $\quad .$. & 45 & 34 \\
\hline I & $\begin{array}{l}\text { Complaining of tightness } \\
\text { of the chest on Mondays } \\
\text { only; symptoms not } \\
\text { progressive }\end{array}$ & 52 & 40 \\
\hline II & $\begin{array}{l}\text { Above symptoms getting } \\
\text { progressively worse and } \\
\text { occurring on days other } \\
\text { than Mondays. Dis- } \\
\text { appearance of symp- } \\
\text { toms when not exposed } \\
\text { to dust }\end{array}$ & 16 & 12 \\
\hline \multirow[t]{3}{*}{ III } & $\begin{array}{l}\text { Complaining of chest } \\
\text { tightness on every work- } \\
\text { ing day and considered } \\
\text { to have some permanent } \\
\text { disability with effort } \\
\text { intolerance when not at } \\
\text { work }\end{array}$ & 15 & 11 \\
\hline & $\begin{array}{l}\text { Not graded because of } \\
\text { incomplete histories }\end{array}$ & 3 & 2 \\
\hline & Total & 131 & \\
\hline
\end{tabular}

* Byssinosis does not occur among weavers and warehousemen in Great Britain. Here all stages of the industrial respiratory disease
of card- and blow-room workers have been included under the term of card- and blow-room workers have been included under the term
byssinosis. Byssinosis, because of its definition for compensation, has often been used only for the disabling stage of the disease.

systemic hypertension which was not necessarily related to emphysema. Heimann, Castberg, Walters, David, and Meyn (1950) in a study of foundrymen in Illinois found that significantly elevated systemic blood pressure levels were related to increasing degrees of pulmonary fibrosis. In the present investigation, of the men between 50 and 60 in the experimental group, there were 17 men who had no evidence of industrial respiratory disease. Their mean pressures were $131.8 \mathrm{~mm}$. systolic and $81.8 \mathrm{~mm}$. diastolic and three of them had hypertension. The mean pressures of the 41 men with industrial respiratory disease were 140.0 systolic and 86.1 diastolic, ${ }^{*}$ and 12 of them had hypertension. The slight differences in the mean pressures and in the incidence of hypertension are not statistically significant; the numbers are small and the reliability of the methods of diagnosing and grading byssinosis is by no means certain. Byssinosis in its earlier stages can at present only

\footnotetext{
* Men with Grade III byssinosis had mean pressures of $144 \cdot 4 / 87 \cdot 5$ $\mathrm{mm}$.

Men with Grades I and II byssinosis had mean pressures of $138 \cdot 9 / 85 \cdot 8 \mathrm{~mm}$.
}

be diagnosed by the occupational and medical histories (Schilling, 1950), and it is probable that in this study there was some error in both the diagnosis and the grade. By adopting more objective methods of assessing pulmonary disability in card- and blow-room workers, it is hoped in a later investigation to get a more reliable assessment of the relationship between byssinosis and systemic hypertension, and also to test the reliability of the clinical grading of byssinosis.

\section{Discussion}

The difference found in the incidence of hypertension among card- and blow-room workers and weavers is not big enough to explain the large difference in their mortality rates shown by the Registrar General for 1921-23 and 1930-32. There are explanations for this discrepancy.

It has already been shown that some of the mortality excess was due to the allocation of respiratory deaths to the cardiovascular group of diseases. The Registrar General's mortality figures relate to periods 20 and 30 years ago, when there was much more dust in the card-rooms than there is today. Although we found a substantial incidence of industrial respiratory disease in the older men, and it may well have been a hang-over from the past, it was less than the incidence 40 years ago when Collis (1909) found $90 \%$ of men of all ages affected.

As the cotton mills in which this investigation was made had no records of the men who had left, we were only able to study the population fit for work. Our data cannot, therefore, give an accurate picture of the true incidence of hypertension in the occupational groups studied. This, however, will not invalidate the relative incidence of hypertension in the two trades unless hypertension is more likely to cause unfitness and disability for work in one trade than in the other through differences in physical demands and environmental conditions. It is known that many people with benign hypertension can live a normal working life for many years without symptoms, if they are kept in ignorance of their condition and not prevented from living a normal life by their medical advisers (Naish, 1946). The physical demands of work in card- and blow-rooms and weaving sheds are more or less the same, but the combined effects on card- and blow-room workers of respiratory disease and hypertension might well make the latter disease more disabling for them than for weavers. If this does happen, it would decrease our chance of finding hypertensives among the card- and blow-room workers we examined. In this respect it may be significant that we found so few card- and blow- 
room workers with hypertension in the 60-65 age group.

It is not possible to state categorically that heredity does not account for the higher incidence of hypertension among the card- and blow-room workers, because of the incompleteness of the family histories. There is, however, a suggestion that hypertension may be related to industrial pulmonary disease. This or some other occupational influence may be the cause of our findings.

If this study had been made 30 years ago when the card-rooms of British cotton mills were very dusty and if the data on cardiovascular mortality could have been analysed more accurately, the results might well have been more conclusive. It would be of interest to know if there is similar but more definite evidence of an occupational hypertension among cotton workers in the other countries where dust suppression methods in cotton mills have been even less successful. Nevertheless, in this country, in spite of the efforts to reduce dust, this investigation has shown that industrial respiratory disease still remains a serious problem among the older men employed in mills spinning the coarser grades of cotton.

\section{Summary}

This paper describes a clinical study in Lancashire cotton mills spinning and weaving the coarser grades of cotton of card- and blow-room workers, who are exposed to fine cotton dust, and weavers and warehousemen who are not so exposed. Special attention was given to the incidence of hypertension. Repeated blood pressures were taken during the examination. Men were considered to be suffering from hypertension when their lowest pressures were at or above both levels of $150 \mathrm{~mm}$. of mercury for the systolic pressure and $90 \mathrm{~mm}$. of mercury for the diastolic pressure.

In the age group $50-59,15$ out of $59(25 \%)$ card- and blow-room workers had hypertension as defined, whereas four $(8 \%)$ out of 50 weavers and warehousemen had hypertension. This difference is statistically significant at the $5 \%$ level.

There was no evidence that this was due to observer error, to anthropometric differences between the two groups, or was related to a higher incidence of renal disease among the card- and blow-room workers. Nor was there definite evidence to suggest that the difference was due to a greater familial tendency to essential hypertension among cardand blow-room workers than among other cotton workers.

Sixty-three per cent. of the card- and blow-room workers had symptoms of byssinosis and there was a suggestive relation between industrial respiratory disease and hypertension, which will be investigated more fully.

We should like to thank the many employers and workers whose cooperation and interest made this study possible, and in particular Mr. Henniker Heaton, of the Federation of Master Cotton Spinners' Associations Ltd., Mr. A. Roberts, of the Card and Blowing Room Operatives and Ring Spinners' Association, Mr. A. Naismith of the Amalgamated Weavers' Association; Dr. J. N. Morris of the Social Medicine Research Unit of the Medical Research Council for much advice and criticism ; Professor Lane and Professor Robert Platt and other colleagues inside and outside the department for their help and advice. We would also like to thank Dr. J. Gregory and Dr. R. F. L. Logan for considerable help with the examinations; Dr. Roscoe for examining the samples of urine ; and Dr. R. Murray and Mr. W. Moore of the Factory Department of the Ministry of Labour and National Service for helping us to select the cotton mills.

\section{REFERENCES}

Ayman, D. (1934). Arch. intern. Med., 53, 792.

British Medical Journal (1947). 1, 727.

Cardiac Society of Gt. Britain and Ireland (1939). Brit. Heart J., $3,261$.

Collis, E. L. (1909). Annual Report of the Chief Inspector of Factories and Workshops for 1908. Home Office [Cd. 4664]. H.M.S.O. London.

Doll, R., and Buch, J. (1950). Ann. Eugen., Lond., 15, 135.

Gelfand, M. L. (1951). Amer. J. Med., 10, 27.

Harvey, P. N. (1939). Appendix to the Report of the Departmental Committee on Compensation for Card Room Workers, p. 19. H.M.S.O., London.

Heimann, H., Castberg, H. T., Walters, F. J., David, W. D., and Meyn, A. W. (1950). U.S.P.H.S. Public Health Service Publ. No. 31, p. 55 seq.

Herndon, R. F. (1946). An Introduction to Essential Hypretension. Springfield, Illinois.

Hill, A. Bradford (1930). Ind. Health Res. Board Rep., No. 59. H.M.S.O., London.

Hines, E. A. (1937). Ann. intern. Med., 11, 593.

Levy, R. L., Hillman, C. C., Stroud, W. D., and White, P. D. (1944). J. Amer. med. Ass., 126, 829 .

McMichael, J. (1948). Edinb. med. J., 55, 65.

McMichael, J. (1948). Edinb. med. J., 55, 65.
Naish, J. M. (1946). Bristol med.-chir. J., 63, 106.

O'Sullivan, J. G., and Dingwall-Fordyce, I. (1950). The Incidence of Byssinosis in the Waste Cotton Industry. Personal communication.

Parkinson, J., and Hoyle, C. (1937). Quart. J. Med., n.s. 6, 59.

Platt, R. (1947). Ibid., n.s. 16, 111 .

Prausnitz, C. (1936). Spec. Rep. Ser. med. Res. Coun., Lond. No. 212.

Robinson, S. C., and Brucer, M. (1940). Amer. J.med. Sci., 199, 819. Rosenthal, S. R. (1930). Arch. Path., Chicago, 10, 717.

Schilling, R. S. F. (1950). Brit. med. Bull., 7, 52.

, and Goodman, N. (1951). British Journal of Industrial Medicine $8,77$.

Symonds, B. (1923). J. Amer. med. Ass., 80, 232.

Treadgold, H. A. (1933). Lancet, 1, 733.

Weitz, W. (1923). Z. klin. Med., 96, 151 . 


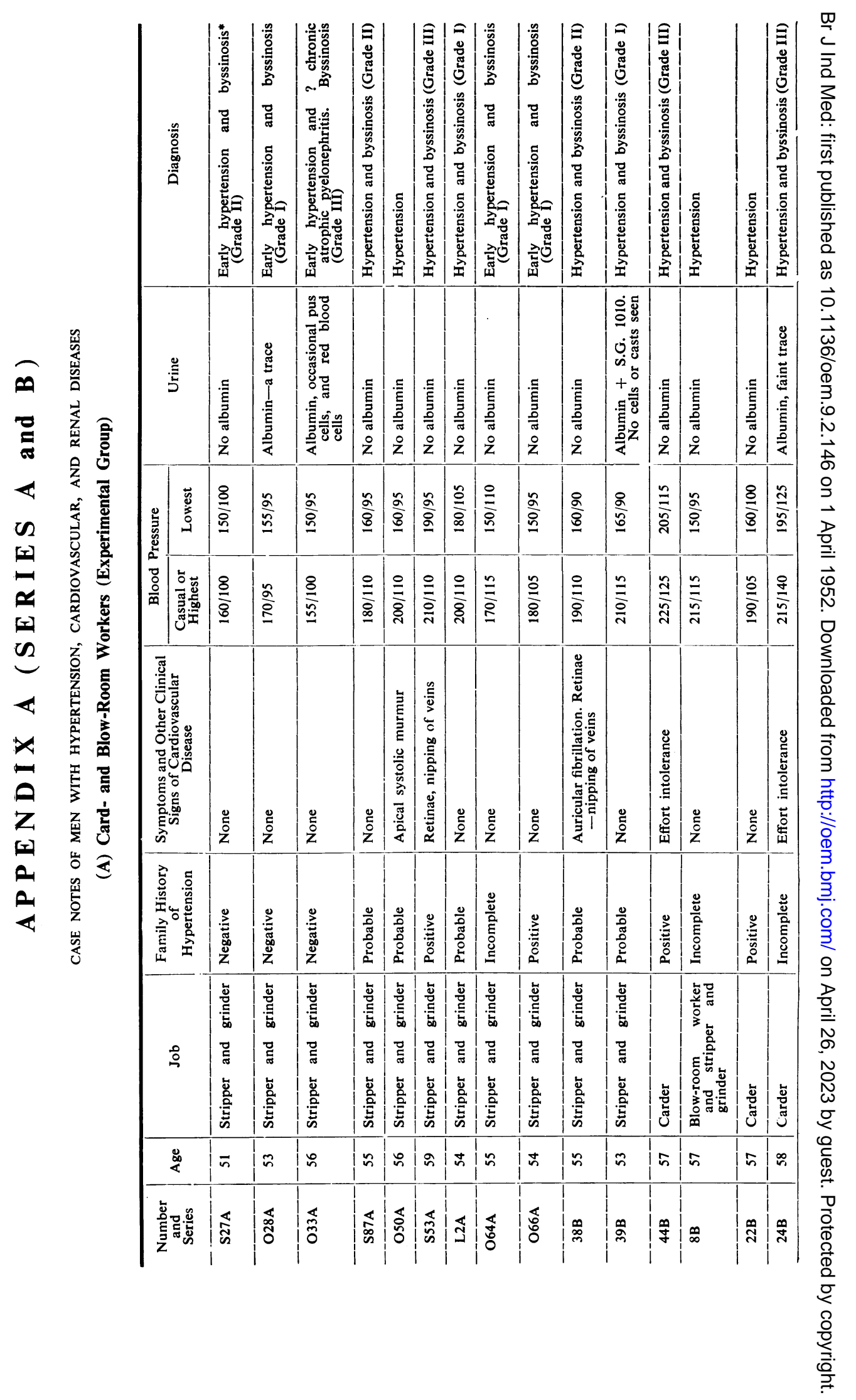




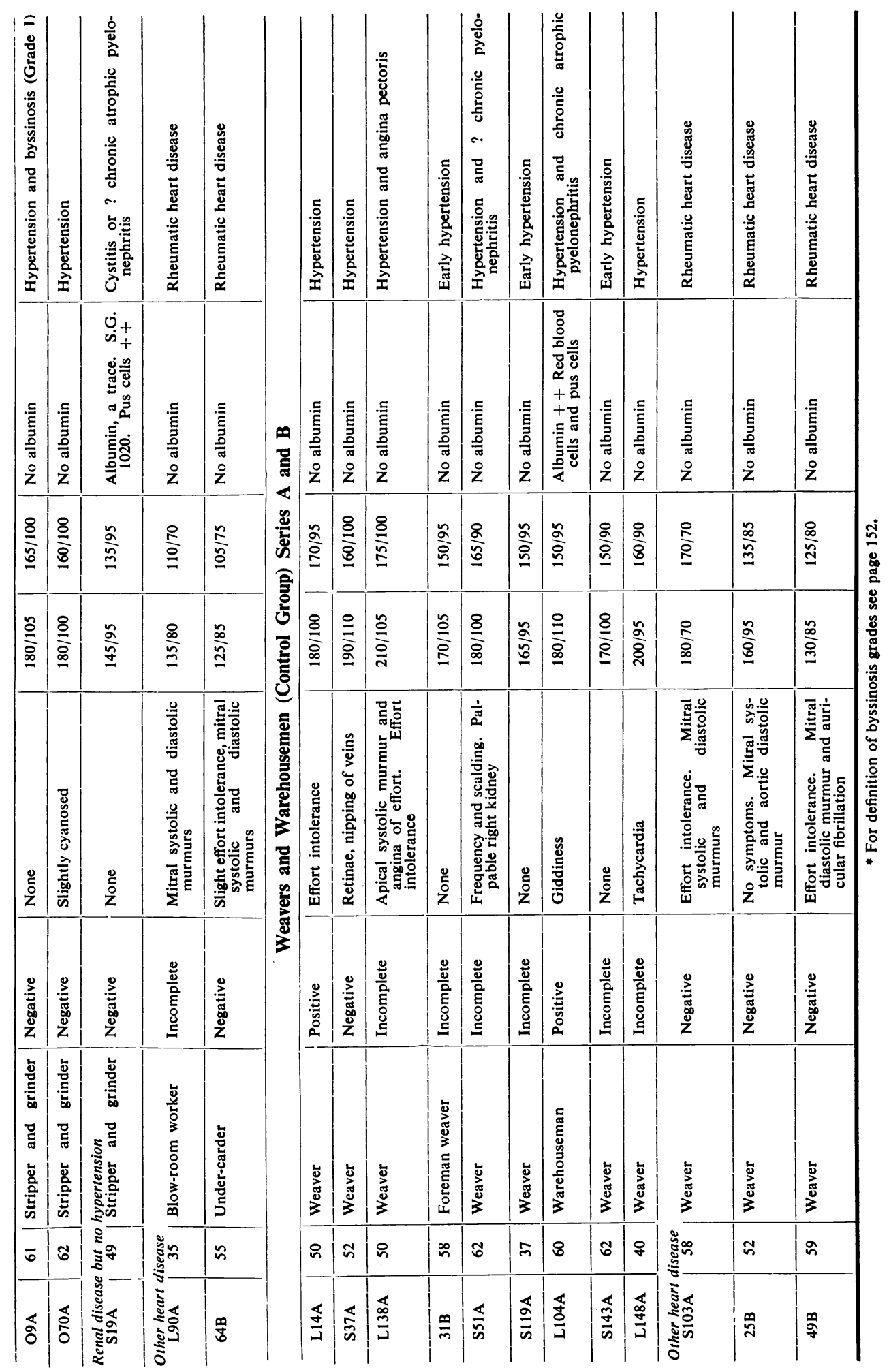

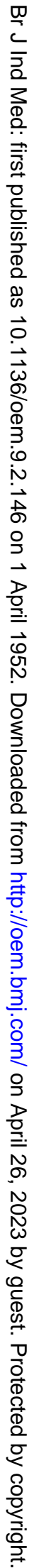


A P P E N D I X B

COMPARISON BETWEEN EXPERIMENTAL AND CONTROL GROUPS FOR AGE AND LENGTH OF TIME IN THE COTTON INDUSTRY

\section{1.-Series A}

\begin{tabular}{|c|c|c|}
\hline Age & $\begin{array}{c}\text { Experimental } \\
\text { Group }\end{array}$ & $\begin{array}{l}\text { Control } \\
\text { Group }\end{array}$ \\
\hline $\begin{array}{l}35- \\
40-\end{array}$ & $\left.\begin{array}{l}12 \\
29\end{array}\right\}(40 \%)$ & $\left.\begin{array}{l}17 \\
17\end{array}\right\}(37 \%)$ \\
\hline $\begin{array}{l}45- \\
50-\end{array}$ & $\left.\begin{array}{l}21 \\
13\end{array}\right\}(33 \%)$ & $\left.\begin{array}{l}22 \\
16\end{array}\right\}(41 \%)$ \\
\hline $\begin{array}{l}55- \\
60-64\end{array}$ & $\left.\begin{array}{l}18 \\
10\end{array}\right\}(27 \%)$ & $\left.\begin{array}{r}12 \\
9\end{array}\right\}\left(23^{\circ}\right)$ \\
\hline Totals & 103 & 93 \\
\hline $\begin{array}{l}\text { Years in } \\
\text { Industry }\end{array}$ & \multirow[b]{2}{*}{$\begin{array}{cc}6 & (6 \%) \\
36 & (35 \%) \\
43 & (42 \%) \\
18 & (17 \%) \\
- & -\end{array}$} & \multirow[b]{2}{*}{$\begin{array}{rr}11 & (12 \%) \\
31 & (33 \%) \\
38 & (41 \%) \\
11 & (12 \%) \\
2 & (2 \%)\end{array}$} \\
\hline $\begin{array}{l}10- \\
20- \\
30- \\
40- \\
50-\end{array}$ & & \\
\hline Totals & 103 & 93 \\
\hline
\end{tabular}

2.-Series B

\begin{tabular}{|c|c|c|c|c|c|}
\hline \multirow{2}{*}{ Age } & \multicolumn{2}{|c|}{ Time in } & \multirow{2}{*}{$\begin{array}{r}\text { Cotton } \\
\text { (Years) } \\
30-\end{array}$} & \multicolumn{2}{|c|}{ Industry } \\
\hline & $<20$ & $20-$ & & $40-$ & Total \\
\hline $\begin{array}{c}\text { Experimental group } \\
50-54 \\
55-59\end{array}$ & - & $\begin{array}{l}2 \\
1\end{array}$ & $\begin{array}{r}12 \\
7\end{array}$ & $\overline{6}$ & $\begin{array}{l}14 \\
14\end{array}$ \\
\hline Total & - & 3 & 19 & 6 & 28 \\
\hline $\begin{array}{cc}\text { Control group } & \\
50-54 & \ldots \\
55-59 & \ldots\end{array}$ & $\overline{2}$ & 1 & $\begin{array}{l}9 \\
3\end{array}$ & $\overline{7}$ & $\begin{array}{l}10 \\
12\end{array}$ \\
\hline Total & 2 & 1 & 12 & 7 & 22 \\
\hline
\end{tabular}

\section{A P P E N D I X C}

INCIDENCE OF HYPERTENSION AND MEANS OF LOWEST PRESSURES OF EXPERIMENTAL AND CONTROL GROUPS IN MILL NOT INCLUDED IN SERIES A AND B

\begin{tabular}{|c|c|c|c|}
\hline & & $\begin{array}{l}\text { Experi- } \\
\text { mental }\end{array}$ & Control \\
\hline Number of men & & 7 & 13 \\
\hline No. above $150 / 90$ level & $\begin{array}{l}\cdots \\
\ldots\end{array}$ & 3 & 3 \\
\hline Mean systolic pressure & • & $152 \cdot 9$ & $135 \cdot 4$ \\
\hline S.E. of mean & $\therefore$ & $17 \cdot 4$ & $4 \cdot \dot{y}$ \\
\hline Mean diastolic pressure & $\cdots$ & $100 \cdot 0$ & $82 \cdot 7$ \\
\hline S.E. of mean . . . & $\cdot$ & $11 \cdot \%$ & $3 \cdot 0$ \\
\hline
\end{tabular}

